\title{
Suça Sürüklenen Çocukların Sosyodemografik Özellikleri ile Suç İlişkisinin İncelenmesi
}

Investigation of The Correlation Between Crime and Sociodemographic Characteristics of Juvenile Delinquency

\author{
Derya KAYMA ${ }^{1}$, Rıza GÖKLER ${ }^{2}$
}

\section{ÖZ}

$\mathrm{Bu}$ çalışmada suça sürüklenen çocukların sosyodemografik özelliklerinin suç davranışı ile ilişkisi incelenmiştir. Araştırma ilişkisel tarama modelinde tasarlanmış olup, çalışma grubu amaçsal örnekleme ile oluşturulmuştur. Çalışmaya 2017 adli yarg1 yılında suç nedeniyle adli mercilerde bulunan, gönüllü, veli izni alınmış 213 ergen katılmıştır. Analiz sonuçlarına göre; sosyodemografik özelliklerden yaş, eğitim durumu, ebeveyn eğitim durumu ve yaşanılan yerleşim yeri ile suç davranışı arasında istatistiki açıdan anlamlı bir ilişki bulunmaktadır. Cinsiyete ve ebeveynle birlikte yaşama durumuna göre suç davranışı farklılık göstermemektedir. Buna göre; yaş arttıkça, eğitim durumu ve ebeveyn eğitim durumu düştükçe suç davranışı artmaktadır. Ayrıca Ankara İli'nin Altındağ ilçesinde yaşayan katılımcıların suç davranışları daha yüksektir.

Anahtar Kelimeler: Çocuk Suçluluğu, Suç Davranışı, Sosyodemografik Özellikler, Suça Sürüklenen Çocuk

\section{ABSTRACT}

In this study, the relationship between sociodemographic characteristics of children dragged into crime and criminal behavior was investigated. The research was designed in a relational screening model, and the study group was formed by purposeful sampling. 213 adolescents who were in the judicial authorities for dragged into crime in the judicial year of 2017, who were volunteer and whose parents were given consent participated were taken in the study. According to the results of the analysis; there is a statistically significant relationship between socio-demographic characteristics as age, education level, parental education level, residetial area and crime behavior. Crime behavior does not differ according to gender and living with parents. According to this; As age increases, educational status and parental education decreases, criminal behavior increases. Also, the criminal behavior of the participants living in Altındağ district of Ankara Province is higher.

Keywords: Juvenile Delinquency, Criminal Behavior, Socio-demographic Characteristics, Children Dragged Into Crime

Bu çalışma Derya Kayma'nın Rıza Gökler danışmanlığında yürüttüğ̈̈ "Ergenlerin Bazı Kișilik ve Aile Özelliklerinin Suç Davranışına Etkisi" başlıklı doktora tezinden üretilmiştir. Çalışmanın etik izni Yıldırım Beyazıt Üniversitesi, Sosyal ve Beşeri Bilimler Etik Kurulu'nun 02.06.2016 tarih, 12105 stra ve 330 nolu kararı ile alınmıştır.

${ }^{1}$ Derya KAYMA, Dr., Sosyal Hizmet, Manisa Celal Bayar Üniversitesi, Kırkağaç Meslek Yüksekokulu, Sosyal Hizmet ve Danışmanlık Bölümü, Sosyal Hizmet Programı, deryakayma@gmail.com, ORCID: 0000-0001-7014-8631

2 Rıza GÖKLER, Prof. Dr., Sosyal Hizmet, Yıldırım Beyazıt Üniversitesi, Sağlık Bilimleri Fakültesi, Sosyal Hizmet Bölümü, rizagokler@gmail.com, ORCID:0000-0002-9821-4095 


\section{GİRIŞ}

Çocuk suçluluğu yetişkin suç kariyerinin en önemli belirleyicisidir. Çocukluk döneminde suç davranışı gelişen bireylerin yetişkinlikte de suça sürüklenme riskleri daha yüksektir. ${ }^{1}$ Gelişim psikolojisine göre çocukluktaki suç davranışı ve suça eğilim problemli bir geçiş evresine denk gelmesi nedeniyle gelecek yaşantıyı daha fazla etkilemektedir. ${ }^{2} \mathrm{Bu}$ nedenle çocuk suçluluğu alanı yıllardır suçluluk ile ilgilenen sosyal hizmet, kriminoloji, psikoloji, sosyoloji, hukuk gibi birçok disiplinin ilgi odağında bulunmaktadır. Dolayısıyla çocukluk döneminde ortaya çıkan suç davranışının nedenlerinin bilinmesi hem önleyici tedbirler alınması hem de rehabilite edici etkili müdahalelerin geliştirilmesi bakımından oldukça önemlidir.

Literatürde ergen suçluluğu veya genç suçluluğu olarak da ifade edilen çocuk suçluluğu çocukların sapmış davranışlarının yasal müdahaleye ihtiyaç duymas $1,{ }^{3}$ çocuğun ceza kanunlarında suç kabul edilen bir eylemi sergilemiş olması sonucunda ceza yargı sistemi ile karşı karşıya kalması ${ }^{4}$ olarak tanımlanmaktadır. Her iki tanımlamada çocuk suçluluğunun hukuki boyutuna vurgu yapılmaktadır. Çocuk suçluluğu ile ilgilenen sosyoloji disiplinine göre çocuğun bulunduğu sosyal değer ve kurallara ters düşmesi, psikoloji disiplinine göre ise bireysel yetersizliklerle çocuğun yasalarla karşı karşıya kalması olarak çocuk suçluluğu açıklanmaktadır. ${ }^{5}$

Çocuklardaki suç davranışını anlayabilmek için çocuğun hem içinde bulundukları ailesel özelliklerin hem de kişisel özelliklerin belirlenmesi önleyici tedbirlerin alınması açısından önemlidir. ${ }^{6}$ Literatüre bakıldığında çocuğa ilişkin kişisel özellikler kapsamında genellikle demografik ve psikolojik değişkenlerin suç ile ilişkisinin araştırıldığ görülmektedir. Baskin, Sommers, Newman ve Newman'a (2013) göre demografik faktörler çocuğun cinsiyeti, yaşı, etnik kökeni, çalışma/okul durumu, madde kullanımı ve zekasıdır. ${ }^{7} \mathrm{Bu}$ çalışma kapsamında da suça sürüklenen çocukların sosyodemografik özellikleri ile suç davranışı ilişkisi incelenmiştir. Sosyodemografik özellikler cinsiyet, yaş, eğitim durumu, ebeveyn eğitim durumu, ebeveynlerle yaşama durumu ve yaşanılan semt olarak sınırlandırılmıştır.

Hirshi ve Gottfredson'a göre yaş ile suç davranışı arasında anlamlı bir ilişki bulunmaktadır. Buna göre; suç davranışı genç ve orta yaşlarda en üst seviyeye çıkmakta, orta yaş sonrasında da bireyin fiziksel yetersizlikler yaşamaya başlaması ile gerilemeye başlamaktadır. ${ }^{1}$ Sweeden, Piquero ve Steinberg (2013)'in gençlik döneminde başlayan suç davranışını incelediği araştırmada ergenlik döneminden sonra suç davranışının \%69 azaldığı belirlenmiştir. ${ }^{8}$ Çocuk suçluluğu alanında yapılan araştırmalara bakıldığında ise suç oranının en yüksek olduğu yaş grubunun 17 yaş olduğu, ${ }^{9-}$ ${ }^{15} 17$ yaş sonrasında ise her yaş diliminde suç davranışının $\% 5$ azaldığg ${ }^{15}$ görülmüştür.

Çocukların suça sürüklenmesindeki bireysel nedenlerden bir diğeri de cinsiyet faktörüdür. Çocuk suçluluğu alanına dair resmi veriler erkeklerin kadınlara oranla daha fazla suça karıştı̆̆ını göstermektedir. Türkiye İstatistik Kurumu'nun 2017 verilerine göre güvenlik birimine getirilen çocukların 92.849'unun erkek, 15.135'inin ise kadin olduğu belirtilmiştir. ${ }^{16} \mathrm{Bu}$ durum çocuk suçluluğunda da cinsiyet açısından önemli bir farklılığın olduğunu göstermektedir. Yapılan araştırma sonuçları da çocuk suçluluğunda erkeklerin daha fazla suça sürüklendiğini göstermektedir. ${ }^{9,12,17-20}$ Ancak bunun tersi olarak Siyez ve Aysan (2007) erkek ve kadın ergenlerin risk alma eğiliminin ve davranışlarının değişmediğini, ${ }^{21}$ Okorodudu (2010) cinsiyetin ergenlerdeki suç davranışında anlamlı bir farklılık oluşturmadığını belirtmektedir. $^{22}$

Literatürde çocukların okula devamlılığının suç ile ilişkili olduğu belirtilmektedir. Leung'un (2003) ergenlerin zamanı değerlendirme durumlarını incelediği çalışmasında sosyal bir kurum olan okula devam etmenin suç için koruyucu bir faktör olduğu belirtilmektedir. ${ }^{23}$ 
Çocuk gelişiminde aile temelli faktörler diğer faktörler olan sosyal çevre ve okul/akran faktörlerinden daha fazla etkiye sahiptir. $^{24} \mathrm{Bu}$ çalışma kapsamında çocuk suçluluğu aile özelliklerinden ebeveynlerle birlikte yaşama durumu ve ebeveyn eğitim durumu değişkenleri ile sınırlandırılarak incelenmiştir. Aile bütünlüğünün bozulmasının suç davranışına etkisi günümüzde tartışılan bir konudur. Yapılan bazı araştırmalar suç ile aile bütünlüğünün bozulması ilişkisini desteklerken ${ }^{23,25-28}$ bazı araştırmalar suça sürüklenen çocukların çoğunluğunun ailesi ile birlikte yaşadığını göstermektedir. ${ }^{6,10,13,14,29}$ Tunceroğlu (2015) ise yapmış olduğu çalışmada aile bütünlüğünün bozulmasının suç davranışı ilişkisinden ziyade mükerrer suç davranışı ile olan ilişkisinin önemini vurgulamıştır. ${ }^{11}$

Suça sürüklenen çocuklar ile yapılan araştırmalar ebeveynlerin eğitim durumunun ilkokul ve altında bir eğitim seviyesinde olduğunu göstermektedir. ${ }^{10,13,14,29}$ Ebeveyn eğitim durumu ile suç ilişkisini inceleyen araştırmalarda ortaya çıkan bir diğer önemli sonuç da toplumsal kültüre bağlı olarak çocukların eğitiminde ve gelişiminde daha fazla sorumluluk alan annelerin eğitim seviyesinin babalarınkinden daha düşük olmasıdır. ${ }^{10,13,30,31}$

Ebeveyn eğitim seviyesi ile paralel bir diğer özellik olan sosyoekonomik seviyedir. Ailenin sosyoekonomik seviyesi ile çocukların suça sürüklenme ilişkisini inceleyen araştırmalar suça sürüklenen çocukların genellikle düşük sosyoekonomik seviyeden, ${ }^{10,11,14,29}$ hatta çoğunun yoksulluk ve açlık sınırındaki ailelerden geldiğini ${ }^{11,14,29}$ göstermektedir. Yaşanılan sosyal çevre bulunulan ekonomik düzeye göre şekillenmektedir. $\mathrm{Bu}$ nedenle suç risklerinin yoğun olduğu bölgelerin daha çok yoksul ve düşük sosyoekonomik seviyedeki yaşam bölgeleri olduğu söylenebilir.

Sonuç olarak bu çalışmada çocuk suçluluğu ile yaş, cinsiyet, eğitim durumu, ebeveynlerle birlikte yaşama, ebeveyn eğitim durumu ve yaşanılan semt gibi sosyodemografik özellikler arasındaki ilişkinin incelenmesi amaçlanmıştır.

\section{MATERYAL VE METOT}

Suça sürüklenen çocukların sosyodemografik özellikleri ile suç davranışı arasındaki ilişkiyi inceleyen bu araştırmada değişkenler arasındaki ilişki değişkenlere müdahale edilmeden incelendiği için bu çalışma nicel araştırma yöntemlerinden ilişkisel tarama modeline bir örnektir.

Araştırmanın evrenini, Ankara'da suç davranışı nedeniyle çocuk adalet sisteminde bulunan ergenler oluşturmaktadır. Amaçsal örnekleme yöntemi ile araştırmaya 2017 Adli yarg1 yılında (Eylül 2016-Temmuz 2017) suç davranışı iddiası nedeniyle çocuk adalet sisteminde bulunan ve yarg1 süreci Ankara Doğu Adliyesi'ne bağlı Ankara 1., 2., 3., 4. Çocuk Mahkemeleri ve 1. Çocuk Ağır Ceza Mahkemesinde devam eden, veli onayı alınmış, gönüllü 213 suça sürüklenen çocuk katılmıştır. Katılımcıların 155'i erkek, 58'i kadındır. Yaşları 13-17 arasında değişen katılımcıların \%61'i 16-17 yaşlarındadır. Katılımcıların yaş ortalaması 15,75'dir.
Araştırma kapsamında bağımsız değişken olan sosyodemografik özellikleri belirlemek amacıyla araştırmacı tarafından geliştirilen Kişisel Bilgi Formu (KBF) kullanılmıştır. Bağımlı değișken olan suç davranıșı düzeyinin belirlenebilmesi için Kaner (2001) tarafından geliştirilen Suç Davranışı Ölçeği (SDÖ) kullanılmıştır. SDÖ ergenler arasında ergenlerin sergilemiş olduğu ve güvenlik güçlerince yakalanmaları durumunda hukuki açıdan suç olarak görülen ve ergeni yasalar ile karşı karşıya getiren davranışları saptamak amacıyla geliştirilmiş bir ölçektir. 896 ergenin katılımı ile geliştirilen ölçek beşli likert tipi toplam 38 maddeden oluşmaktadır. Dokuz faktörlü bir yapıya sahip ölçekten toplam puan da alınabilmektedir. Ölçekten alınabilecek toplam puan 38-152 arasında değişmektedir. Düşük puan düşük suç davranışını, yüksek puan yüksek suç davranışını ifade etmektedir. Ölçeğin tümü için Cronbach 
Alpha değeri .93'dür. ${ }^{32}$ Bu çalışmada SDÖ toplam puanı kullanılmıştır ve çalışma için Cronbach Alpha güvenirlilik katsayısı değeri .96 olarak hesaplanmıştır.

\section{Araştırmanın Etik Yönü}

Araştırma etiği kapsamında Yıldırım Beyazıt Üniversitesi Sosyal ve Beşeri Bilimler Etik Kurulu'ndan 02.06.2016 tarihinde Etik Kurul Onayı ve Adalet Bakanlığı Hakimler ve Savcılar Yüksek Kurulu'ndan 30.06.2016 tarihinde uygulama izni alınmıştır. Araştırma kapsamında kullanılan SDÖ için ölçeği geliştiren Sema Kaner' den mail yoluyla kullanım izni alınmıştır.

Araştırmanın katılımcılarının 18 yaş altında olması nedeniyle araştırmada bilgilendirilmiş onam formu kullanılarak gönüllülük esası aranmış ayrıca ebeveyn izni alınabilmesi için de veli onam formu kullanılmıştır.

\section{İşlem ve Veri Analizi}

Veri toplama işlemi Eylül 2016- Temmuz 2017 arasında yapılmıştır. Verilerde \% 10'un üzerinde eksiklik olanlar araştırma dışında tutularak, 43 suça sürüklenen çocuğa ilişkin bilgiler veri setine dahil edilmemiş, veri analizine 213 ergenden elde edilen veriler değerlendirmeye alınmıştır.

Verilerin analizinde katılımcilardan toplanan bilgiler Sosyal Bilimler için İstatistik Paket Programı kullanılarak bilgisayar ortamına işlenmiştir. Analizlerde hata payı üst sınırı 0,05 olarak alınmıştır. Analizlerde öncelikle değişkenlerin dağılım özellikleri histogram grafiği ile çarpıklık ve basıklık katsayıları ile incelenmiştir. Buna göre normal dağılım özelliği gösteren değişkenler arasındaki ilişkiler Pearson Korelasyon Analizi, Bağımsız Gruplar için T Testi Analizi; Bağımsız Gruplar Tek Yönlü Varyans Analizi kullanılarak incelenmiştir.

\section{BULGULAR VE TARTIŞMA}

Araştırmanın bu bölümünde suça sürüklenen çocukların sosyodemografik özellikleri ile suç davranışı arasındaki ilişkiyi gösteren bulgulara yer verilmiştir.

"Yaş ile suç davranışı arasında anlamlı bir ilişki var mıdır?" sorusuna yanıt aramak amacıyla değişkenler arasındaki ilişki Pearson Korelasyon Analizi ile incelenmiş ve sonuçlar Tablo 1'de verilmiştir.

Tablo 1. Yaş ile Suç Davranışı Arasındaki İlişki

\begin{tabular}{cllrc}
\hline Değişkenler & $\mathbf{N}$ & Ort & \multicolumn{1}{c}{ Ss } & \multicolumn{1}{c}{ r } \\
\hline SDÖ & 213 & 62,33 & 25,73 & - \\
Yaş & 213 & 15,75 & 1,09 & $0,269^{* *}$ \\
${ }^{* *} p<0,01$ & & & &
\end{tabular}

Suça sürüklenen çocukların suç davranışı ile yaşları arasında düşük düzeyde ve pozitif yönlü anlamlı bir ilişki bulunmaktadır, $r=$ $0,269, \mathrm{p}<0,01$. Buna göre yaş arttıkça suç davranışının arttığı söylenebilir. Alan yazında yaş ile suç davranışı arasında anlamlı bir ilişkinin bulunduğ $\mathrm{u}^{6,9,22,26,33}$ belirtilmektedir. Yaş ile suç davranışı arasındaki bu ilişkinin temelinde bu yaş döneminin kısacası ergenlik döneminin gelişimsel özelliklerinin bulunduğu söylenebilir. Psikososyal, bilişsel ve fiziksel gelişimin devam ettiği bu dönemde kimlik arayışında olan ergenler bireysel değişimlerle birlikte etkileşim halinde olduğu diğer sistemlerle (aile, akran, okul gibi) olan ilişkilerinde de hızlı değişimler yaşamaktadır. Fırtınalı dönem olarak adlandirılan bu dönemde ergenler farkı heyecan arayışları, kabul görme, kendini ispatlama gibi gereksinimlerle riskli davranışlara daha fazla eğilim gösterebilmektedir.

"Suç davranışı cinsiyete göre anlamlı bir farklılık göstermekte midir?" sorusuna yanıt aramak amacıyla $t$ testi analizi yapılmıştır ve bulgular Tablo 2'de verilmiştir.

Tablo 2. Cinsiyete Göre Suç Davranışı Farklılaşma Sonuçları

\begin{tabular}{lrrcccc}
\hline $\begin{array}{l}\text { Değişk } \\
\text { enler }\end{array}$ & N & Ort & Ss & Sd & t & p \\
\hline Kadın & 58 & 59,58 & 26,77 & 211 & 0,95 & 0,343 \\
Erkek & 155 & 63,35 & 25,30 & & & \\
\hline p $>0,05$ & & & & & &
\end{tabular}

Tablo 2'ye göre araştırmaya katılan kadınların suç davranışı puan ortalaması ( $\bar{X}=59,58)$ erkeklerin suç davranışı puan 
ortalamasından $(\bar{X}=63,35)$ daha düşüktür.

$\mathrm{Bu}$ durum kadınların erkeklere göre daha düşük suç davranışı sergilediğini göstermektedir. Ancak bağımsız gruplar $\mathrm{t}$ testi sonucuna göre; $\mathrm{t}(211)=0,95$, $\mathrm{p}=0,343>0,05$ olduğu için suç davranışı puan ortalamaları arasındaki bu fark istatistiki açıdan anlamlı bir farklılık değildir. Buna göre cinsiyet suç davranışı açısından önemli bir belirleyici olmamaktadır. Araştırmanın bu bulgusu Okorodudu'nun (2010) ergenlerin suç davranışını, Siyez'in (2006) ergenlerdeki antisosyal davranışları incelediği araştırma sonuçları ile paralellik göstermektedir. Ancak alan yazında bulunan araştırma sonuçları ile de farkl1lık göstermektedir. ${ }^{6,9,12,17-20,26,33,34 ~}$ Zaman içerisinde toplumsal rollere ilişkin sosyal algıdaki değişim suç davranışında cinsiyetin belirleyici olmamasında önemli rol oynamış olabilir. $\mathrm{Bu}$ bağlamda daha çok bağımsızlaşan kadınlar ergenler gibi benzer suç riskleri ile karşı karşıya kalabilmektedir.

"Suç davranışı eğitim durumlarına göre anlamlı bir farklılık göstermekte midir?" sorusuna yanit aramak amaciyla katılımcıların suç davranışı ortalamaları tek yönlü varyans analizi ile incelenmiş olup elde edilen sonuçlar Tablo 3'de sunulmuştur.

Varyans analizi sonuçları, farklı eğitim durumunda bulunan suça sürüklenen çocukların suç davranışı puan ortalamaları arasında anlamlı bir fark olduğunu göstermektedir, $\quad\left(F_{3 ; 209}=21,23 ; p<0,05\right)$. Başka bir deyişle ergenlerin suç davranışları eğitim durumuna göre anlamlı olarak değişmektedir. $\mathrm{Bu}$ farklılaşmanın hangi gruplar arasında olduğunu bulmak amaciyla yapılan Scheffe testinin sonuçlarına göre ortaokul ve lise eğitimine devam eden ergenlerin suç davranışı ortalamalarının ilkokul ve ortaokul mezunu ergenlerden daha düşük olduğu belirlenmiştir. $\mathrm{Bu}$ durum orta ve lise eğitimine devam eden ergenlerin ilkokul ve ortaokul mezunu olan ergenlerden daha az suç davranışı sergilediğini göstermektedir. $\mathrm{Bu}$ bulguda dikkat çeken unsur okul yaşantısı devam eden (ilkokul ve ortaokul mezunu) ve devam etmeyen (ortaokul ve lise eğitimine devam eden) suça sürüklenen çocukların suç davranışları arasındaki anlamlı farklılıktır. Bu farklılığın temel nedenlerinin okul yaşantısının sonlanmasıyla ergenin okula bağlılığının sonlanması, okul denetiminden uzak kalması, boş zamanların etkili değerlendirememesi ve erken yaşta çalışma hayatına girmesi ile açıklanabilir. Çocuk suçluluğunun önlenmesinde sosyal kontrolün önemini belirten Hirchi'ye göre sosyal bağlar ve bağlanma suç davranışının engellenmesinde önemli birer etkendir. ${ }^{1}$ Okul bu sosyal bağlardan biri olmakla birlikte sosyal kontrolün önemli parçalarından birini oluşturmaktadır. Okul ortamında ergen gün içinde okul ve okulu oluşturan sistemlerin denetimi altında bulunmakta böylece sosyal çevrenin suç risklerinden uzak kalabilmektedir. Literatürde okul günlerinin sayısının arttırılmasının mülkiyet suçlari ${ }^{35}$, zorunlu eğitim yılının yükseltilmesinin de hem şiddet hem de mülkiyet suçlarında düşüşe neden olduğ $\mathrm{u}^{36}$ belirtilmektedir. Anderson (2014) Amerika Birleşik Devletleri'nde zorunlu okullaşmaya yönelik yasal düzenleme ile okul terki yaşının 16'dan 18'e yükseltilmesinin çocukların tutuklanmasında \%10'luk bir düşüşe neden olduğunu belirtmektedir. ${ }^{36} \mathrm{Bu}$ nedenle çocukların okul yaşantısının devam ediyor olması suç davranışı oluşumunda engelleyici bir etkisi söz konusu olabilmektedir. 
Tablo 3. Suç Davranışı Puanlarının Eğitim Durumlarına Göre Farklılaşma Sonuçları

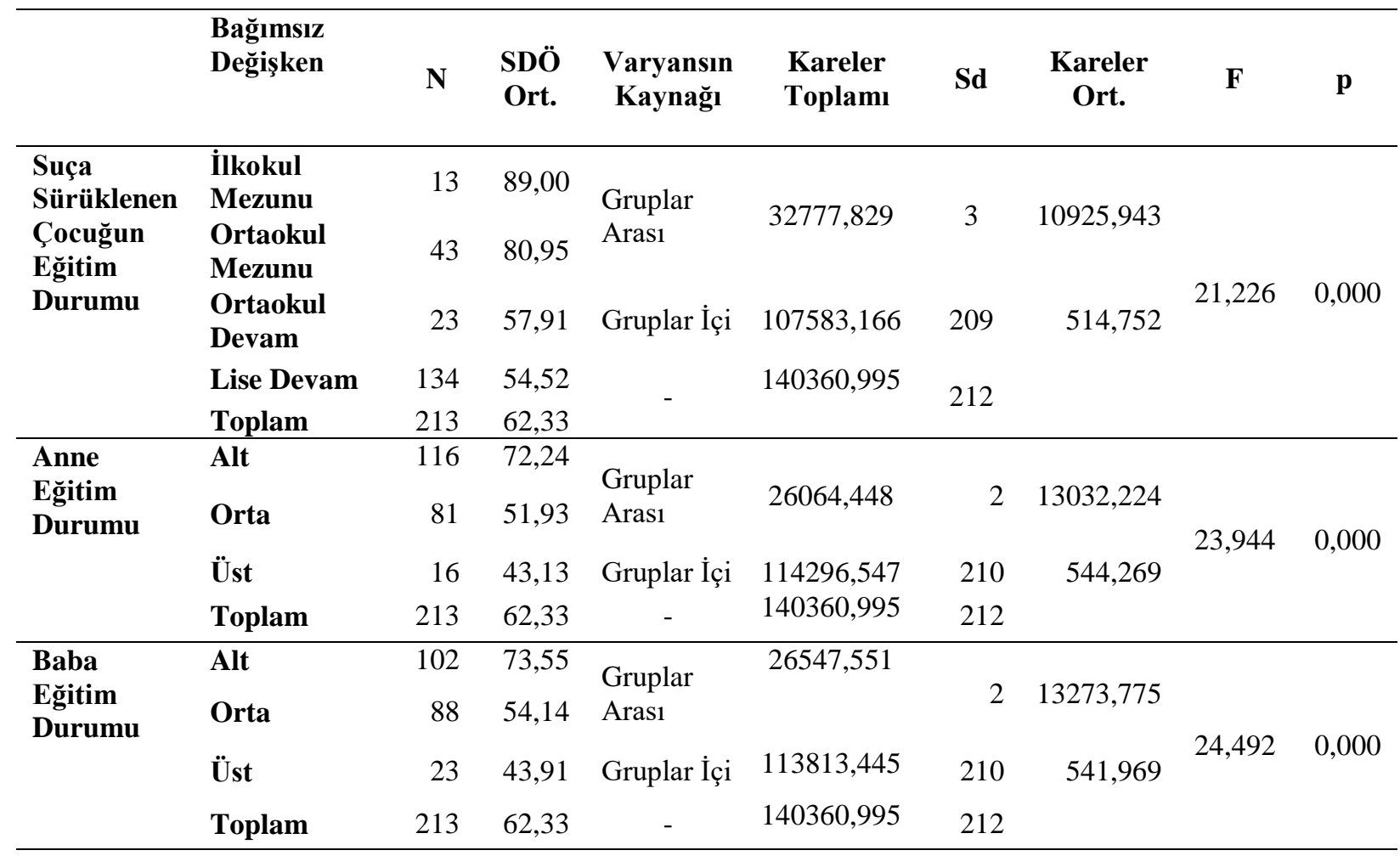

"Suç davranışı anne eğitim durumuna göre anlamlı bir farklılık göstermekte midir?" sorusuna yanıt aramak amaciyla suça sürüklenen çocukların suç davranışı ortalamaları anne eğitim durumuna göre incelenmiş olup elde edilen sonuçlar Tablo 3'de sunulmuştur. Analizlere anne eğitim durumu üç kategoride alınmıştır. Alt eğitim durumunda okuryazar olmayan, okuryazar olan ve ilkokul mezunu; orta eğitim durumunda ortaokul ve lise mezunu; üst eğitim durumunda ise üniversite, yüksek lisans/doktora mezunu olanlar alınmıştır.

Tablo 3'e bakıldığında anne eğitim durumu ile suça sürüklenen çocukların suç davranışı puan ortalamaları arasındaki farkın anlamlı olduğu görülmektedir, $\left.\left(\mathrm{F}_{2 ; 210}\right)=23,94 ; \mathrm{p}<0,05\right)$. Başka bir deyişle anne eğitim durumunun farklılaşması katılımcıların suç davranışı ortalamalarında anlamlı bir farklılık yaratmaktadır. Bu farklılığın hangi gruplar arasında olduğunu bulmak amaciyla yapılan Scheffe testinin sonuçlarına göre; anne eğitim durumu alt seviyede olan ergenlerin suç davranışı puan ortalaması anneleri orta ve üst eğitim seviyesinde bulunan ergenlerin suç davranışı ortalamasından daha yüksektir. Bir başka deyişle annesi ilkokul ve altında eğitim seviyesinde olan çocuklar daha fazla suç davranışı sergilemektedir.

"Suç davranışı baba eğitim durumuna göre anlamlı bir farklılık göstermekte midir?" sorusuna yanıt aramak amaciyla suça sürüklenen çocukların suç davranışı ortalamaları baba eğitim durumuna göre incelenmiş olup elde edilen sonuçlar Tablo 3'de sunulmuştur. Analizlere baba eğitim durumu anne eğitim durumunda olduğu gibi üç kategoride analizlere alınmıştır.

Tablo 3'e göre baba eğitim durumu ile katılımcıların suç davranışı puan ortalamaları arasında anlamlı bir fark olduğu görülmektedir, $\left.\left(F_{2 ; 210}\right)=24,49 ; p<0,05\right)$. Başka bir deyişle katılımcıların suç davranışları, baba eğitim durumuna bağlı olarak anlamlı bir şekilde değişmektedir. Gruplar arasındaki farklılıkları belirlemek amaciyla yapılan Scheffe testin analizi babası alt eğitim seviyesinde olan suça sürüklenen çocukların suç davranışı puan ortalaması orta ve üst eğitim seviyesinde babaya sahip olanların puan ortalamalarından anlamlı derecede yüksek bulunmuştur. Bir başka ifadeyle 
ilkokul ve altında eğitim seviyesinde babaya sahip olan çocuklar ortaokul ve üstü eğitim seviyesinde bulunan çocuklardan daha fazla suç davranışı sergilemektedir. Çocuk suçluluğuna ilişkin literatür incelendiğinde suça sürüklenen çocukların ebeveynlerinin eğitim durumunun çoğunlukla ilkokul ve altında bir eğitim seviyesinde olduğu, toplumsal kültüre bağlı olarak çocukların eğitiminde ve gelişiminde daha fazla sorumluluk alan annelerin eğitim seviyesinin babaların eğitim seviyesine göre daha düşük olduğu görülmüştür. ${ }^{10,13,14,26,27,29}$ Ebeveyn eğitimine bağlı olarak ergenlerin suç davranışında görülen bu farklılık yapılan çalışmalarla da anlamlı bulunmuştur.6,21,33 Araştırma bulguları literatürde belirlenen sonuçlar ile paralellik göstermektedir. Araştırmaya katılan ergenlerin büyük bir çoğunluğunun ebeveyn eğitiminin ilkokul ve altında bir eğitim seviyesinde bulunduğu, annelerin eğitim seviyesinin babalarınkinden daha düşük olduğu, ebeveyn eğitim durumu düştükçe ergenlerin suç davranışı ortalamasının arttı̆̆ı bulgusuna ulaşılmıştır. Ebeveyn eğitimine göre bulunan bu farklılık hem anne hem de baba eğitim durumu için istatistiki açıdan anlamlı bir farklılıktır. Çocukların ve ailelerinin karşılaştıkları problemlerle başetme becerileri kazanabilmesi için özellikle ebeveynlerin eğitim durumu önemlidir. Ebeveynlerin eğitim durumu düştükçe çocuğun eğitiminde ve gelişiminde daha fazla yetersizlikler yaşanabilmekte hatta pedagojik olmayan çocuk yetiştirme davranışları görülebilmektedir. Bunun sonucu olarak da ebeveynleri tarafindan yeterli düzeyde desteklenemeyen çocukların gelişimleri olumsuz etkilenebilmekte ve beraberinde davranış sorunları eşlik edebilmektedir. Kisacas1 ebeveynlik becerilerinin gelişmesinde eğitim durumu önemli bir unsur olabilmektedir.

"Suç davranışı ebeveyn ile birlikte yaşama durumuna göre anlamlı bir farklılık göstermekte midir?" sorusuna yanıt aramak amacıyla katılımcıların suç davranışı ebeveynle birlikte yaşama durumuna göre değişip değişmediğine bağımsız gruplar için $\mathrm{t}$ testi analizi yapılmıştır. Çalışmanın t testi sonuçları Tablo 4'de verilmiştir.

Tablo 4. Ebeveynle Birlikte Yaşama Durumuna Göre Suç Davranışı Farklılaşma Sonuçları

\begin{tabular}{lrccccc}
\hline & N & Ort & Ss & Sd & t & p \\
\hline Var & 181 & 62,12 & 25,08 & 211 & 0,282 & 0,775 \\
Yok & 32 & 63,53 & 29,55 & & & \\
\hline $\mathrm{p}>0.05$ & & & & & &
\end{tabular}

Tablo 4'de ebeveynleri ile birlikte yaşayan katılımcıların suç davranışı puan ortalaması ( $\bar{X}=62,12$ ) birlikte yaşamayan ergenlerin suç davranışı ortalamasından $(\bar{X}=63,53)$ daha düşük olduğu görülmesine rağmen bu fark istatistiksel açıdan anlamlı bulunmamıştır. Çocuk suçluluğu alanında yapılan çalışmalar suç davranışı sergileyen ergenlerin çoğunluğunun ebeveynleriyle birlikte yaşamaya devam etmediğini belirtirken bazı araştırmalar ebeveynlerle birlikte yaşama durumunun devam ettiğini göstermektedir. ${ }^{6,10,13,14,23-25,28,29}$ Sonuç olarak ebeveynlerle birlikte yaşama durumu ile suç davranışı arasındaki ilişkiye dair araştırma bulgusu ebeveynlerle birlikte veya ayr1 yaşamanın suç davranışı için belirleyici bir etken olmadığını, ebeveynlerle birlikte yaşamaktan çok çocuk-ebeveyn ilişkisinin ve etkileşiminin niteliğinin suç davranışının oluşumunda daha etkili olabileceğini düşündürmektedir. $\mathrm{Bu}$ nedenle ebeveynin fiziksel varlığından çok ebeveynin niteliksel varlığ suçun oluşumunda daha önleyici bir etken olabilmektedir.

"Suç davranışı yaşanılan semte göre anlamlı bir farklılık göstermekte midir?" sorusuna yanıt aramak için suça sürüklenen çocukların suç davranışı ortalamaları yaşanılan semte göre incelenmiş olup elde edilen sonuçlar Tablo 5'de sunulmuştur. 
Tablo 5. Suç Davranışı Puanlarının Yaşanılan Semte Göre Farklılaşma Sonuçları

\begin{tabular}{|c|c|c|c|c|c|c|c|c|}
\hline $\begin{array}{l}\text { Bağımsız Değişken } \\
\text { Yaşanılan Semt }\end{array}$ & $\mathbf{N}$ & $\begin{array}{l}\text { SDÖ } \\
\text { Ort. }\end{array}$ & $\begin{array}{c}\text { Varyansın } \\
\text { Kaynağı }\end{array}$ & $\begin{array}{l}\text { Kareler } \\
\text { Toplamı }\end{array}$ & Sd & $\begin{array}{c}\text { Kareler } \\
\text { Ort. }\end{array}$ & $\mathbf{F}$ & $\mathbf{p}$ \\
\hline $\begin{array}{l}\text { Keçiören } \\
\text { Çankaya } \\
\text { Mamak }\end{array}$ & $\begin{array}{l}37 \\
20 \\
53\end{array}$ & $\begin{array}{l}47,81 \\
49,80 \\
64,81\end{array}$ & $\begin{array}{l}\text { Gruplar } \\
\text { Arasi }\end{array}$ & 35251,623 & 5 & 7050,325 & & \\
\hline $\begin{array}{l}\text { Altındağ } \\
\text { Yenimahalle } \\
\text { Diğer* }\end{array}$ & $\begin{array}{l}54 \\
32 \\
17\end{array}$ & $\begin{array}{l}81,81 \\
52,50 \\
57,53\end{array}$ & Gruplar İçi & 105109,372 & 207 & 507,775 & 13,885 & 0,000 \\
\hline Toplam & 213 & 62,33 & - & 140360,995 & 212 & & & \\
\hline
\end{tabular}

*Diğer: Etimesgut, Polatl, Pursaklar ve Sincan

Tablo 5'e bakıldığında yaşanılan yere göre katılımcıların suç davranışı puan ortalamaları arasında anlamlı bir fark olduğu görülmektedir $\quad\left(\mathrm{F}_{5 ; 207}\right)=13,89$; $\mathrm{p}<0,05)$. Başka bir deyişle suça sürüklenen çocukların suç davranışları, yaşanılan semte bağlı olarak anlamlı bir şekilde değişmektedir. $\mathrm{Bu}$ değişimin hangi gruplar arasında olduğunu bulmak amaciyla yapılan Scheffe testi sonuçları; Altındağ semtinde yaşayan katılımcıların suç davranışı puan ortalamasının Keçiören, Çankaya, Yenimahalle, Mamak ve diğer semtlerde yaşayanların suç davranışı puan ortalamalarından anlamlı düzeyde daha yüksek olduğunu göstermektedir. Sonuç olarak Altındağ semtinde yaşayan çocuklar daha fazla suç davranışı sergilemektedir. Yaşanılan bölgeler arasında bu farklılık ekolojik perspektif ile açıklanabilir. Uluğtekin'e (2012) göre, ekolojik perspektifte birey çevresindeki sistemlerle karşılıklı etkileşim içinde değişmektedir ve gelişmektedir. ${ }^{37} \mathrm{Bu}$ değişim ve geliş̧im sürecinde bazı çevresel ve bireysel nedenler bu süreci olumsuz etkileyebilmekte ve bunun sonucu olarak suç davranışı gelişebilmektedir.

Yaşanılan bölgenin özellikleri ile suç davranışını açıklayan sosyolojik kuramlardan biri olan gerilim kuramının öncüsü Merton ekonomik açıdan dezavantajlı bölgelerdeki alt sinıftaki çocukların sosyal yapı içinde bir üst sınıfa geçiş yapabilmek için suça sürüklenebileceğini belirtmektedir. ${ }^{38}$ Alt kültür kuramına göre ekonomik açıdan daha alt düzeyde yaşayan çocuklar üst ve orta sınıftakilerin değer sistemleri ile sürekli çatışma yaşamakta, bu çatışma ile öz güven duygusu zedelenmekte, kendi kültüründeki çocuklar ile çeteleşme içine girmekte ve suça sürüklenmektedir. ${ }^{39}$ Sosyal öğrenme kuramına göre; çocuklarda suç davranışının etkileşim halinde olunan sosyal sistemlerde suç davranışlarının model alınması ve taklit edilmesi ile gerçekleşebileceği belirtilmektedir. Tüm bu kuramlar çevrenin suç davranışı oluşumunda önemli etkisini belirtmektedir. En yüksek suç davranışı sergileyen çocukların yaşadığı Altındağ bölgesinin sosyoekonomik özelliklerine bakıldığında sosyoekonomik düzeyin diğer bölgelerden daha düşük olduğu, kentleşmenin henüz tamamlanmamış olmasından dolayı gecekondulaşmanın ve göç alımının halen devam ettiği görülmektedir. Coşar (2005)'e göre, şehir bölgelerindeki farklı suç oranlarının düşük sosyoekonomik düzey, yüksek göç alımı ve gecekondulaşma ile ilgili olduğu, dolayısıyla suça sürüklenen çocukların da göç olgusu ile birlikte daha çok gecekondu bölgelerde yaşadığ 1 belirtilmektedir. ${ }^{40} \mathrm{Bu}$ nedenle yaşanılan bölgenin özelliklerinin çocuğun suça sürüklenmesinde etkili olabileceği söylenebilir. 


\section{SONUÇ VE ÖNERILER}

Araştırma sonuçlarına göre; ergenlik döneminde yașa bağlı olarak suç davranıșının arttığ1, düşük eğitim seviyesinde olan ve okula devam etmeyen çocukların daha fazla suç davranışı sergilediği belirlenmiştir. Bu kapsamda ergenlik döneminde olan çocuklara yönelik okul temelli koruyucu ve önleyici hizmetlere, okul sosyal hizmet uygulamalarının başlatılmasına yönelik yasal düzenlemelerin hızlı bir şeklide hayata geçirilmesine ihtiyaç duyulmaktadır. Okul sosyal hizmeti uygulamalarında önleyici programlar geliştirerek belirli aralıklarla okul terk riski bulunan öğrencilerin belirlenmesi ve risk altındaki çocukların okula bağlliklarının güçlendirilmesi için psikoeğitsel çalışmalar yapılmasının suç davranışının önlenmesinde etkili olabileceği düşünülmektedir. Ayrıca çocukların okula bağl1lıklarının güçlenmesi için okul içinde kültürel ve sportif faaliyetlerin arttırılmasının hem serbest zamanlarını etkili değerlendirilmesi hem de sosyal çevredeki suç risklerinden de korunabilmesi için yararlı olabileceği düşünülmektedir. Araştırma bulgularına göre yaşanılan semte göre çocukların suç davranışında anlamlı farklılık bulunmaktadır. $\mathrm{Bu}$ nedenle özellikle dezavantajlı bölgelerde okul içi eğitici ve geliştirici programlara daha fazla ihtiyaç duyulmaktadır.

Araştırmada ergenlik döneminde suç davranışının yaş ile birlikte arttığı belirlenmiştir. Özellikle Türkiye'deki çocuk adalet sisteminde ceza sorumluğunun 12 yaş ile başladığı düşünüldüğünde, 12 yaş öncesinde çocukların adalet kavramı, suçun hukuki yaptırımları, riskleri ve korunma yöntemleri gibi konularda farkındalık kazanmalarına yönelik düzenli olarak psikoeğitim programlarının uygulanması önerilmektedir.

Araştırma sonuçlarına göre ebeveyn eğitim seviyesi düştükçe çocukların suç davranışı artmaktadır. Araștırmanın bir diğer bulgusu da ebeveynlerle birlikte yaşama veya yaşamama durumunun suç davranışında bir farklılık oluşturmamasıdır. Bu durum fiziksel açıdan çocuğun yanında olmaktansa psikososyal açıdan çocuğa destek olmanın daha önemli olduğunu düşündürmektedir. $\mathrm{Bu}$ kapsamda çocukların suç davranışlarının engellenebilmesi için ebeveynlerin ebeveynlik becerilerini geliştirmeleri gerekmektedir. Dolayısıyla ergenlik dönemi özellikleri, çocukla iletișim ve sağlıklı ebeveyn uygulamaları konularında ebeveynlerin becerilerini geliştirmelerine yönelik hizmetlerin geliștirilmesi gerekmektedir. Ebeveynlerin bu konularda bilgi ve becerilerini geliştirmeleri durumunda çocukların suça eğilimli gelişimlerinde erken uyarı işaretlerini görebileceği ve etkili ebeveyn müdahaleleri sergileyebileceği düşünülmektedir.

KAYNAKLAR

1. Hirschi, T. and Gottfredson, M. (1983). "Age and The Explanation of Crime". The American Journal Sociology, 89 (3), 552-584.

2. Yavuzer, H. (2011). Çocuk ve Suç. İstanbul: Remzi Kitabevi.

3. İçli, T.G. (2007). Kriminoloji. Ankara: Seçkin Yayınları.

4. Akyüz, E. (2000). Ulusal ve Uluslararası Hukukta Çocuğun Haklarının ve Güvenliğinin Korunması. Ankara: Milli Eğitim Basımevi.

5. Hablemitoğlu, Ş. (2011). "Aile İçi Şiddeti Önlemek Çocuk Suçluluğunu ve Mağduriyeti Azaltır Mi?". Hançerli S, Sevinç B, Gürer C, Öner M.C. (Ed.). Suça Sürüklenen ve Mağdur Çocuklar (93-102). Ankara: Sabev Yayınlar1.
6. Balkaya, A. ve Ceyhan, E. (2007). "Lise Öğrencilerinin Suç Davranışı Düzeylerinin Bazı Kişisel ve Ailesel Nitelikler Bakımından İncelenmesi". Aile ve Toplum Dergisi, 3 (11), 13 27.

7. Baskin, A.R, Sommers, D.R, Newman, I.B. and Newman, J.P. (2013). "The Intersectionality of Sex, Race and Psychopathology In Predicting Violent Crimes". Criminal Justice and Behavior, 40, 1068-1091.

8. Sweeten, G, Piquero, A.R. and Steinberg, L. (2013). "Age and The Explanation of Crime". Journal Youth Adolescence, 10. doi: 10.1007/s10964-013-9926-4.

9. Kaner, S. (2001). "Anababa Denetimleriyle Ergenlerin Suç Kabul Edilen Davranışları Arasındaki İlişskinin İncelenmesi". İçinde: 1.Ulusal Cocuk ve Suç: Nedenler ve Önleme Çalışmaları Sempozyum Bildiri Kitabı (229-254). Ankara: Yeniden Özgürlük Vakfı Yayını. 
10. Sahinli, K. (2012). Cocuk Suçluluğuna Sebep Olan Ailesel Faktörler: Ankara Kapalı Çocuk Ve Gençlik Ceza İnfaz Kurumu'nda Bulunan Tutuklu ve Hükümlü Çocuklar Üzerine Bir Çalışma. Güvenlik Bilimleri Enstitüsü, Yüksek Lisans Tezi, Ankara.

11. Tunceroğlu, Z. (2015). Suça Sürüklenen Çocuklarda Mükerrerliğin İrdelenmesi. Adli Tıp Enstitüsü, Doktora Tezi, İstanbul.

12. Delikara, İ. (2001). Ergenlerin Akran İlișkileri ile Suc Kabul Edilen Davranışlar Arasındaki İlişkinin İncelenmesi. İçinde: 1.Ulusal Çocuk ve Suç: Nedenler ve Önleme Çalışmaları Sempozyum Bildiri Kitibı (147160). Ankara: Yeniden Özgürlük Vakfı Yayını.

13. Kara, İ, Demircan, E, Hançerli, S, Sevinç, B, Cüneyt, G, Kaya, A. ve Öner, M.C. (2011). "Suça Sürüklenen Çocuklar İçin Yeni Yaklaşımlar: Diyarbakır Örneği". Hançerli, S, Sevinç, B, Gürer, C, Öner, M.C. (Ed.). Suça Sürüklenen ve Mağdur Çocuklar (353-365). İstanbul: Sabev Yayını.

14. Dinç, A. (2013). Çocuk Suçluluğunda Ailenin Rolü. Sosyal Bilimler Enstitüsü, Yüksek Lisans Tezi, Kırıkkale.

15. McKoy, D.H. and Cui, M. (2013). "Parental Control, Adolescent Delinquency and Young Adult Criminal Behavior", J Child Fam Study,22, 836-843.

16. Türkiye İstatistik Kurumu. (2017). https://biruni.tuik.gov.tr/medas/ $\quad ? \mathrm{kn}=98 \&$ locale $=$ tr. Erişim Tarihi: 15 Ekim 2017.

17. Hodgins, S, Kratzer, L. and McNei,1 T.F. (2001). "Obstetric Complicatinons, Parenting and Risk of Criminal Behaviour". Arch Gen Psychiatry, 58, 746-752.

18. Robles, S.C. and Gamble, W. (2006). "ParentAdolescent Process and Reduced for Delinquency:The Effect of Gender for Mexican American Adolescents". Youth and Society, 37 (1), 375-392.

19. Ünal, H. (2010). "Ebeveynlerle Olan İlișkiler, Sapkın Arkadaşlar ve Sapkın Davranışlar". Sosyoloji Araştırmalar Dergisi, 13 (2), 215-248.

20. Şahin, F.Y. (2015). "Predicting Delinquency Levels in Turkish Adolescents". Hacettepe Üniversitesi Eğitim Bilimleri Dergisi, 30 (1), 313-323.

21. Siyez. D.M. and Aysan. F. (2007)."Ergenlerde Görülen Problem Davranışların Psiko-Sosyal Risk Faktörleri ve Koruyucu Faktörler Açısından Yordanması". Uludağ Üniversitesi Eğitim Fakültesi Dergisi, 20(1), 145-171.

22. Okorodudu, G.N. (2010). "Influence of Parenting Styles on Adolescent Delinquency in Delta Central Senatorial District". Edo Journal of Counselling, 3 (1), 58-86.

23. Leung, A. (2003). "Delinquency, Schooling and Work: Time Allocation Decision of Youth". Applied Economics Letters, 10, 943-949.

24. Duncan, G.J, Boisjoly, J. and Harris, M.K. (2001)."Sibling, Peer, Neighbour and Schoolmate Correlations as Indicators of The Importance of The Context For Adolescent Development". Demography, 38(3), 437-447.

25. Zimmermann, G. (2006). "Delinquency of Male Adolescents: The Role of Alexithymia and FamilySstructure". Journal of Adolescent, 29, 321-332.

26. Akduman, G.G, Akduman, B. ve Cantürk, G. (2007) "Çocuk Suçluluğunda Bazı Kişisel ve Aile Özelliklerinin İncelenmesi". Türk Pediatri Araștırmaları Dergisi, 42, 156-161.
27. Uludağlı, N.P. (2011). Suça Karıșmıs ve Karısmamış Ergenlerin Aile, Akran, Mahalle Özellikleri ile Psikolojik ve Akademik Niteliklerinin İncelenmesi, Sosyal Bilimler Enstitüsü, Doktora Tezi, Ankara

28. Çoban, S. (2014). "Bazı Sosyal Etkenlerin Cocuk Suçluluğu ile İlişkisi Üzerine Karșılaștırmalı Bir Araștırma". Hacettepe Üniversitesi Edebiyat Fakültesi Dergisi, 31 (2), 77-95.

29. Afşin, R.Ş. (2017). Suça Sürüklenen Çocuklar ile Suça Sürüklenmeyen Cocukların Algıladıkları Anne Baba Tutumları, Bağlanma Stilleri ve Benlik Algılarının İncelenmesi. Eğitim Bilimleri Enstitüsü, Yüksek Lisans Tezi, Ankara.

30. Öter, A. (2003).Çocuk Suçluluğunun Toplumsal Nedenleri: Antalya Örneği. Sosyal Bilimleri Enstitüsü, Yüksek Lisans Tezi, Isparta.

31. Kunt, V. (2003). Suç ve Çocuk. Sosyal Bilimler Enstitüsü, Yüksek Lisans Tezi, Ankara.

32. Kaner, S. (2001). "Suç Davranışı Ölçeği Geliştirme Calışması". İçinde: 1.Ulusal Çocuk ve Suç: Nedenler ve Önleme Calıșmaları Sempozyum Bildiri Kitabı (1-13). Ankara: Yeniden Özgürlük Vakfı Yayını.

33. Bulut, F. (2010). Ergenlerde Görülen Kuraldıșı Davranıșların Aile İşlevselliği, Aile Risk Faktörü ve Yaşam Kalitesi Açısından İncelenmesi. Yüksek Lisans Tezi. Sosyal Bilimler Enstitüsü, Ankara.

34. Kim, H.S. and Kim, H.S. (2008). "The Impact of Family Violence, Family Functioning and Parental Partner Dynamics on Korean Juvenile Delinquency". Child Psychiatry Human Development, 39, 439-453.

35. Luallen, J. (2006). "School's Out Forever: A Study of Juvenile Crime, at-Risk Youths and Teacher Strikes". Journal of Urban Economics, 59, 75-103.

36. Anderson, M. (2014). "In School and Out of Trouble? The Minimum Dropout Age and Juvenile Crime". The Revief of Economics and Statistics, 96 (2), 318-331.

37. Uluğtekin, S. (2012). Denetimli Serbestlik Altındaki Gençler ve Ailelerine İlişkin Araştırma: İhtiyaçlar ve Beklentiler. Ankara: Özgürlüğünde Yoksun Gençlerle Dayanışma Derneği Yayını.

38. Kızmaz, Z. (2005). "Sosyolojik Suç Kuramlarının Suç Olgusunu Açıklama Potansiyelleri Üzerine Bir Değerlendirme". Cumhuriyet Üniversitesi Sosyal Bilimler Dergisi, 29 (2), 149-174

39. Shoemaker, D.J. (2010). Theories of Delinquency: An Examination of Explanations of Delinquent Behavior. New York: Oxford University Press.

40. Coşar, Y. (2005). "Kentleșen Türkiye'de Çocuk Suçluluğu". Türk Tabipler Birliği Dergisi, 56, 281- 327. 